\title{
THE EFFECTS OF PURIFIED SHEEP LUTEINIZING HORMONE ON THE GUINEA-PIG OVARY
}

\author{
R. DEANESLY \\ A.R.C. Institute of Animal Physiology, Babraham, Cambridge
}

(Received 22nd November 1965)

Luteinizing hormone (Ovine, NIH-LH-s7 from the National Institutes of Health, Bethesda, U.S.A.) has been administered subcutaneously in normal saline $(0.5 \mathrm{mg} / \mathrm{ml})$ to female guinea-pigs for a study of its effects on ovulation and the cycle.

The animals were examined daily for vaginal changes; the first day of vaginal closure after oestrus (corresponding in general to the morning of the vaginal plug in mated females), was recorded as Day 0 and the following days as (luteal) Days 1, 2, etc. In most experiments a single dose of LH was given; the ovaries were examined at autopsy, and one or both sectioned serially after fixation in Bouin's fluid. Preliminary tests in cyclic females showed that $200 \mu \mathrm{g}$ LH would stimulate ovulation within $24 \mathrm{hr}$ and also follicular luteinization.

Fifteen unmated non-parous females with a regular cycle of about 16 days, each received one injection of $200 \mu \mathrm{g}$ LH on Day 4, 5, 6 or 7; eight were killed 4 to 10 days later and the rest left till after the next oestrus. One animal was injected in consecutive cycles and killed during the second. The average length of a cycle including an LH injection was 18 days-perhaps a slight extension but within the normal range. In about half the females the vaginal membrane ruptured briefly or was near rupture, after the LH injection.

The induced corpora lutea, one to four in each ovary, developed normally and no superovulation was seen. Many follicles did not ovulate but reacted to the luteinizing hormone by a characteristic clumping of the granulosa cells; sometimes these became luteinized, with the egg retained in the follicle. Degenerating follicles of all sizes are common in the untreated guinea-pig and the limited number of ovulations after $\mathrm{LH}$ indicates that its action was restricted to follicles at an appropriate stage of development. It was clear from the normal appearance of the original cyclic corpora lutea as well as from the length of the cycles that sheep LH had no immediate luteolytic effect.

The induced and cyclic corpora lutea were examined in three females killed 7 days after the LH injection given on luteal Day 7; the two types were histologically distinguishable. In one female both sets of corpora lutea had regressed and the follicles were pre-ovulatory. In another, both sets still looked large and healthy and in the last the cyclic corpora lutea were shrunken and vacuolated while the induced corpora lutea, in marked contrast, retained eosinophil luteal cells with numerous mitotic figures. 
In other tests $100 \mu \mathrm{g}$ LH regularly induced ovulation in adults, but $50 \mu \mathrm{g}$ only in $1 / 3$ females; $20 \mu \mathrm{g}$ or $10 \mu \mathrm{g}$ in seven females gave negative results. In the rabbit, $10 \mu \mathrm{g}$ of a similar extract, injected intravenously, would cause ovulation (Stormshak \& Casida, 1964).

In immature 270 to $290 \mathrm{~g}$ females given single doses of 20 to $200 \mu \mathrm{g} \mathrm{LH}$ only one female showed a normal ruptured follicle; other ovaries had luteinized or disorganized follicles with retained eggs. A 22 days pregnant female given $200 \mu \mathrm{g} \mathrm{LH}$ had young corpora lutea 3 days later in addition to normal pregnancy corpora lutea. Rowlands (1956) made a study of the fate of corpora lutea induced in pregnant guinea-pigs by intravenous chorionic gonadotrophin and observed that the two sets would coexist. No attempt was therefore made to repeat this work with sheep $\mathbf{L H}$.

In the hysterectomized guinea-pig the luteal phase is prolonged and may last 4 months after which a fresh ovulation occurs; this can be accelerated by removal of the corpora lutea (Loeb, 1927). Ovulation during the luteal phase can, however, be induced by $\mathrm{LH}$ in untreated hysterectomized females as well as in those where the luteal phase has been experimentally interrupted (Deanesly \& Perry, 1965). Six females, 32 to 43 days after hysterectomy, each received a single LH injection; three had $100 \mu \mathrm{g}$, two had $200 \mu \mathrm{g}$ and one had $300 \mu \mathrm{g}$ and they were killed 1 to 14 days later. All showed corpora lutea from fresh ovulations which developed normally in addition to the large corpora lutea of hysterectomy. Only in one ovary, 2 days after the induced ovulation, were the original corpora lutea of hysterectomy somewhat below the average size; there was no evidence that $\mathrm{LH}$ had induced premature regression of the original corpora lutea.

Five females in mid-cycle were given $100 \mu \mathrm{g}$ LH daily after hypophysectomy and were killed 9 or 10 days later. In four of them the corpora lutea had obviously regressed and in one of these a fresh ovulation had apparently taken place, of which the corpora lutea were well-vascularized but small. In spite of the repeated injections, the hormone had no luteotrophic effect on the original cyclic corpora lutea.

In the present dosage, sheep LH will induce ovulation but is neither luteotrophic nor luteolytic in the guinea-pig; it does not significantly prolong the normal cycle or preserve corpora lutea in hypophysectomized females. Equally it does not cause regression of existing cyclic or pregnancy corpora lutea. Different effects might be seen from extracts of the animal's own pituitary, which Hill (1934) found rather inactive.

I am indebted to Dr J. S. Perry for carrying out the hypophysectomies. I wish to express my thanks to the National Institutes of Health, Bethesda, U.S.A., for the supply of luteinizing hormone.

\section{REFERENCES}

Deanesly, R. \& Perry, J. S. (1965) Corpus luteum control in hysterectomized guinea-pigs. F. Endocr. 32, 153.

HiLl, R. T. (1934) Species variation in the gonadotropic activity of the hypophysis. F. Physiol., Lond. 83, 137. 
Loes, L. (1927) The effects of hypophysectomy on the system of sex organs and on the periodicity of the sexual cycle in the guinea-pig. Am. F. Physiol. 83, 202.

Rowlands, I. W. (1956) The corpus luteum of the guinea-pig. Ciba Foundation Coll. Aging, 2, 69.

Stormshak, F. \& CAsida, L. E. (1964) Effect of gonadotropins on corpora lutea of pseudo-pregnant rabbits. Endocrinology, 75, 321. 